\title{
International Journal on Organic Electronics (IJOE)
}

ISSN: 2278 - 1293 [Online]; 2319 - 4359 [Print]

\section{http://airccse.org/journal/IJOE/ijoe.html}

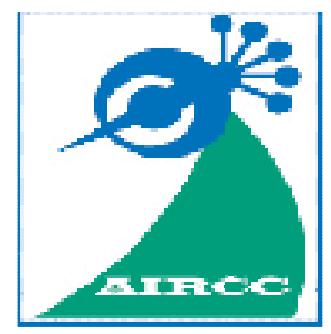

ISSN : 2278 - 1293 [Online] $2319-4359$ [Print

\section{International Journal on Organic Electronics} (IJOE)

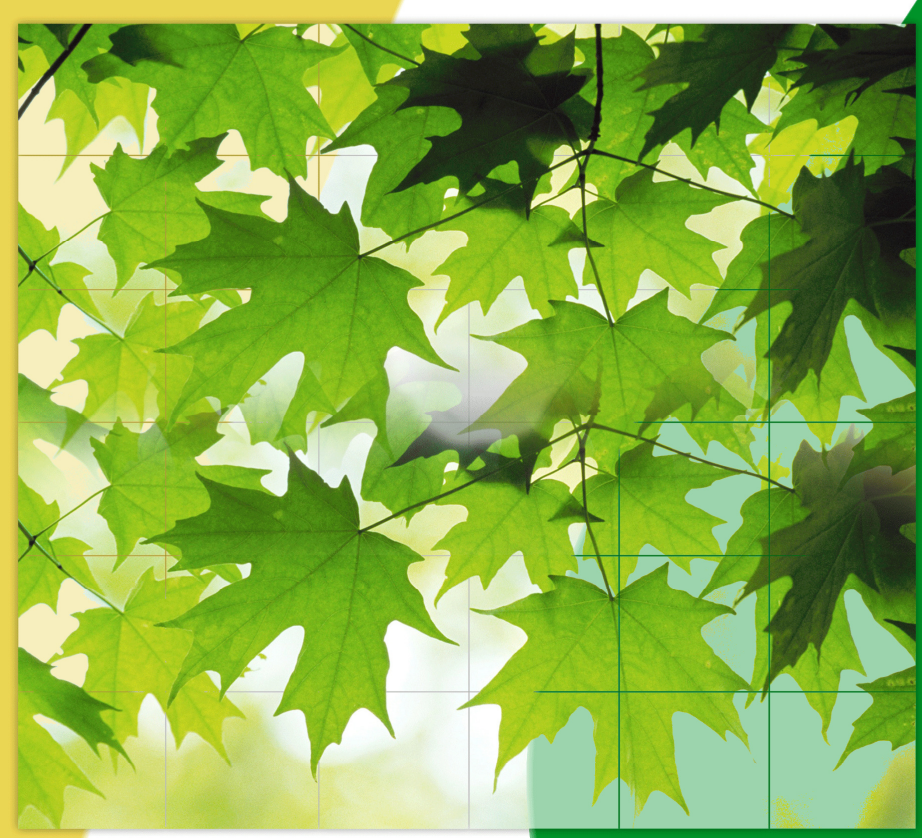

AIRCC Publishing Corporation 


\section{SCOPE OF THE JOURNAL}

This journal focuses on novel organic materials and characterization of organic and nanoscale electronic devices, such as high-performance organic thin film transistors, carbon nanotube transistors, inorganic semiconductor nanowire field-effect transistors, and organic/inorganic hybrid radial superlattices. The Journal serves as a platform to discuss original research work in experiment, theory and applications covering areas of research such as physics, chemistry, and engineering of materials with applications to organic electronics and optoelectronics.

Topics of interest include but are not limited to:

$>$ Discovery and development of conductive polymers

$>$ Physics of liquid crystals

$>$ Physics of polymer light emitting diodes

$>$ Physics of small molecule based light emitting diodes

$>$ Thin film transistor technologies

$>$ Organic solar cells

$>$ From single transistors to logical circuits

Pixel circuits of organic light emitting displays 


\section{Members of the Editorial Board}

Editorial Board Members:

Abdul Kadir Ozcan, The American University, Cyprus

Anitha V R, SreeVidyanikethan Engineering College, India

Beheshti A, Elect. Eng. School, Iran

Brajesh Kumar Kaushik, Indian Institute of Technology-Roorkee, India

David C. Wyld, Southeastern Louisiana University, USA

Eric Renault, Institut Telecom - Telecom SudParis, Evry, France

Ford Lumban Gaol, University of Indonesia

Ioannis Karamitsos, University of Aegean, Greece

Jacques DEMERJIAN, Communications \& Systems, France

Jan Zizka, SoNet/DI, FBE, Mendel University in Brno, Czech Republic

Kaliammal N, RVS College of Engineering \&Technology, India

Krzysztof Walkowiak, Wroclaw University of Technology, Poland

Lu Ye, Broadcom Corporation, USA

Mohankumar N, Amrita Vishwa Vidyapeetham, India

Nirav J. Joshi, University of California, USA

Rakesh K Vaid, University of Jammu, India

Rakhesh Singh Kshetrimayum, Indian Institute of Technology, Guwahati, India

Ramakrishnan H.V, Bharath university, India 
Ramayah, Universiti Sains Malaysia, Malaysia

Reza Ebrahimi Atani, University of Guilan, Iran

Sarmistha Neogy, Jadavpur University, India

Sattar B. Sadkhan, University of Babylon, Iraq

Selma Boumerdassi, Cnam/Cedric, France

Solange Rito Lima, University of Minho, Portugal

Vikrant Vij, Jaypee University of Information Technology, India

\section{Contact Us}

Here's where you can reach us: ijoejournal@yahoo.com (or) ijoejournal@airccse.org 


\section{Paper Submission \& Manuscript preparation Guide}

\section{Paper Submission}

Authors are invited to submit papers for this journal through E-mail: ijoejournal@airccse.org Submissions must be original and should not have been published previously or be under consideration for publication while being evaluated for this Journal. For paper format download the template in this page.

\section{$\underline{\text { Manuscript Template }}$}

\section{Review Process}

Submissions are accepted for review with the understanding that the same work has been neither submitted to, nor published in, another publication. Simultaneous submission to other publications will result in immediate rejection of the paper. Papers are not within the journal scope will be rejected immediately after the pre review process.

All manuscripts will be subject to a well established, fair, unbiased peer review and refereeing procedure, and are considered on the basis of their significance, novelty and usefulness to the Journals readership. The reviewing structure will always ensure the anonymity of the referees \& it will be reviewed by 3 experts in the field. The review output will be one of the following decisions:

\section{Accept}

2. Accept with minor changes

3. Weak Accept with major changes

\section{Reject}

The review process may take approximately two $\sim$ three months to be completed. The Editor reserves the right to reject a paper if it does not meet the aims and scope of the journal, if it is not revised well.

\section{Publication charges: 120 USD (Maximum 20 pages)}

\section{Publication Frequency- Quarterly}

\section{January, April, July, October}

\section{Copy Right Form}

Email the journal secretary at ijoejournal@airccse.org to receive the copy right form 